\section{Evidence for a Relation between Creatine Phosphate Level and Polarity of the Cerebral Cortex}

THE surface of the cerebral cortex in rats is 15 $20 \mathrm{mV}$. positive against other electrically indifferent sites $^{1,2}$. This steady potential can serve as an indicator of brain survival ${ }^{3,4}$.

In the present study we attempted to characterize metabolic processes that might participate in maintaining normal cortical polarity. For this purpose the levels of some metabolites were determined in the rat brain during the various phases of steady potential changes caused by transitory brain ischæmia and following resuscitation. Rats an esthetized with 'Dial' were used throughout. The polarity of the cerebral cortex was measured between an area damaged by thermocoagulation and the normal cortical surface using a chopper direct-current amplifier and cathode ray oscillograph. Ischæmia was induced by a modification of the method of Opitz and Thorn ${ }^{5}$. After exposing the trachea, the neck of the rat is compressed by a rubber band. Although some blood still goes to the head through the spinal and vertebral arteries under these conditions, there is a characteristic decrease in cortical polarity with a half-time roughly equal to that after decapitation. From the time of compression artificial respiration was applied through the free trachea so that cardiac activity remained normal. After 10 or $20 \mathrm{~min}$. the rubber band was released and the return of polarity observed. In various ohasas of repolarization animals were

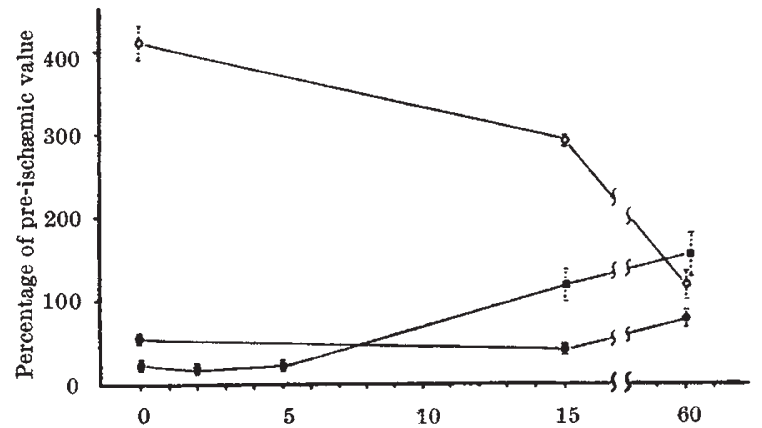

(a) Time after end of ischæmia (min.)

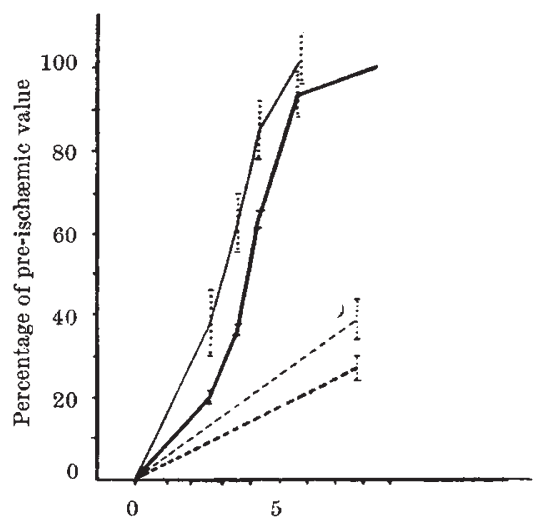

(b) Time after end of ischæmia (min.)

Fig. 1. Changes of ( $a$ ) glycogen ( - - ) , glucose ( $\square$ - ) lactic acid $(\mathrm{O}-\mathrm{O})$ and $(b)$ ereatine phosphate (thin line) and cortical polarity (thick line) after $10 \mathrm{~min}$. (full lines) or $20 \mathrm{~min}$. (interrupted lines) ischæmia. Vertical dotted lines indicate standard error of the mean killed by immersion in liquid nitrogen. Glycogen ${ }^{6}$, glucose $^{7}$, lactic acid ${ }^{8}$ and creatine phosphate ${ }^{9}$ were determined in the hemispheres.

At the end of the $10 \mathrm{~min}$. of ischæmia, when cortical polarity had disappeared almost completely, glycogen, in agreement with the literature, was down to 52 per cent, glucose to 26 per cent and creatine phosphate to unmeasurable values, while lactic acid had risen to 411 per cent of the original value. During resuscitation these changes gradually disappeared. Complete repolarization of the cerebral cortex was attained already after 8-9 min., when the above metabolites were still considerably decreased (Fig. la). Statistical analysis of $75 \mathrm{cor}$ related pairs of values for repolarization and creatine phosphate-levels shows a close correlation $(r=0.61$ $\pm 0.07)$. Renewal of the original creatine phosphatelevel precedes that of cortical polarity by a fraction of a minute (Fig. 1b). From the above and from what is known about cerebral cortical metabolism it seems reasonable to assume that a causal relationship exists between the level of creatine phosphate and cortical polarity. Experiments with 20-min. ischæmia show that this correlation is not accidental. Repolarization under such conditions is much slower, but the correlation between the cortical steady potential and creatine phosphate-level remains unchanged.

The inability of other author ${ }^{10-13}$ to find a direct relation between creatine phosphate or adenosine triphosphate decrease and disappearance of spontaneous electroencephalogram activity or evoked potentials during anoxia or ischæmia, may be explained by the fact that these forms of cerebral activity are due to synaptic organization of neurones and the corresponding specific metabolism of brain mediators. The cortical steady potential, on the other hand, is a result of potential differences between various parts of the cell membrane of the cortical neurones sustained by active transport of ions. Renewal of polarity during resuscitation is not dependent, therefore, on a return of glycogen, lactic acid and glucose to normal levels, but rather on a restoration of creatine phosphate, or possibly of other high-energy phosphates serving as a direct source of energy for active transport through the cell mem. branes.

\section{J. Kr̆IVÁNEK \\ J. BURE Š \\ O. BUREŠOVÁ}

Physiological Institute,

Czechoslovak Academy of Sciences, $\mathrm{Na}$ Cvičišti 2,

Prague 6.

Sept. 24.

${ }^{1}$ Burr, H. S., and Harman, P. J., Trans. Amer. Neurol. Assoc., 65, 11 (1939).

${ }^{2}$ Bures, J., EEG Clin. Neurophysiol., 9, 121 (1957).

"Bureš, J, and Burȩ̌vá, O., Pflüg. Arch., 264, 325 (1957).

- Benešová, O., Burešová, O., and Bureš, J., Arch. Exp. Path. Pharmakol., 231, 550 (1957).

${ }^{5}$ Opitz, E., and Thorn, W., Pflüg. Arch., 251, 369 (1949).

${ }^{6}$ Kerr, s. E., J. Biol. Chem., 116, 1 (1936).

"Gey, K. F., Biochem. J., 64, 145 (1956).

${ }^{8}$ Barker, S. B., and Summerson, W. H., J. Biol. Chem., 138, 535 (194i).

${ }^{9}$ Alexeyeva, A. M., Biochimia, 17, 119 (1952).

${ }^{30}$ Stone, W. E., Marshall, C., and Nims, L. F., Amer. J. Physiol. 132, 770 (1941).

$"$ Kety, S. S., and Schmidt, C. F., J. Clin. Invest., 27, 484 (1948).

12 Allbaum, H. G., Noell, W. K., and Chinn, H. J., Amer. J. Physiol., 174, $408(1953)$ ${ }^{13}$ Thorn, W. Pfeiderer, G., Frowein, R. A., and Ross,
I., Pflüg. Arch., 261, 334 (i955). 